\title{
TRENDS IN PRESS COVERAGE OF FEMINIST ACTIVITY IN THE UAE MEDIA: AN ANALYTICAL STUDY
}

\author{
Dr. Alaa Makki Abdul Hadi ${ }^{1}$, Dr. Marcelle Issa Al Jwaniat 2 \\ 1 University of Sharjah, United Arab Emirates \\ 2 Yarmouk University, United Arab Emirates
}

D0I: https://doi.org/10.29121/granthaalayah.v9.i3.2021.3712

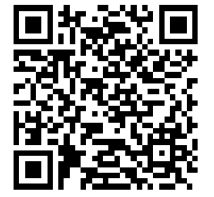

Article Type: Research Article

Article Citation: Dr. Alaa Makki Abdul Hadi, and Dr. Marcelle Issa Al Jwaniat. (2021). TRENDS IN PRESS COVERAGE OF FEMINIST ACTIVITY IN THE UAE MEDIA: AN ANALYTICAL STUDY. International Journal of Research GRANTHAALAYAH, 9(3), 26-46. https://doi.org/10.29121/granthaa layah.v9.i3.2021.3712

Received Date: 14 February 2021

Accepted Date: 19 March 2021

Keywords:

Press Coverage

UAE Media

Feminist Activism

\section{ABSTRACT}

This study seeks to shed light on Arab societies in general and the Emirati society in particular, as we find that customs and traditions have given the conservative form of women,

Which, in turn, is reflected in the entirety of its relations, and its social and cultural processes in particular are closely related to the media institution that reproduced this model by adopting conservative contents, except in very few cases, which is often associated with some feminist institutions.

In this study, the researchers focused on identifying the most important shapes, templates, trends, and areas occupied by all of these coverage. And then determine its contents and meanings. that is through analyzing the coverage and its types and all the arts of journalistic editing, News coverage is made up of the type of news and report, while the explanatory coverage is by the type of press article Investigation and press dialogue, as for the documentary coverage, it is related to the means of highlighting, whether they are news or non-news photos, figures and drawings.

\section{INTRODUCTION}

In the era of digital communication, it has become clear that the power and influence of the media message is linked to the availability of a number of economic, social, political, and cultural conditions that stain it with the type and direction of the thought that it expresses, and then it becomes obvious to say that the media institution does not operate except within the general framework decreed to her, and within the goals it seeks to achieve. In this context, it should be noted here that the media discourse of the media institution is influenced by the society to which it belongs, and the values, ideas and trends that this community holds, all of which contribute to determining the form and content of the media discourse through its reach to the masses.

If we have to try to approach the contents of media coverage of women's issues in the media, we must first acknowledge that the media carry a specific culture, which is the culture of the society to which it belongs. Not only that, but it also goes beyond just spreading the prevailing culture of society to reproduce it. And to generate them again, in ways and forms that are in line and in harmony with the modern developments and trends active in advanced societies that emphasize supporting and strengthening the trends of activating the role of women in society and measuring the level of civilization, and the progress made by society in any country in the world, which in turn is reflected in democracy in that. Society, due to the news, ideas and topics it contains.

(C) 2021 The Author(s). This is an open access article distributed under the terms of the Creative Commons Attribution License, which permits unrestricted use, distribution, and reproduction in any medium, provided the original author and source are credited. 
The peculiarity of the woman's subject, as a social one, with its close relationship with the cultural, religious and social heritage, stems from her uniqueness with a degree of complexity and intertwining, and her need for a temporal extension that allows for dialogue, interaction and constructive accumulation, and the maturity of a set of subjective and objective conditions, all of which, unlike other subjects or problems, give her slow movement.

If we focus on Arab societies in general and UAE society in particular, religion, customs and traditions have given it the conservative form of women, which in turn has been reflected in all its relationships and social and cultural processes in particular, closely related to the media institution that reproduced this form by adopting conservative contents, with the exception of cases There are very few, and often they are linked to some feminist institutions with an open, enlightening, change-oriented approach based on a deeper and comprehensive understanding of religion and social and moral values.

And if the Emirati press has dealt with coverage of women's news, this study seeks to identify the most important forms, molds, trends, and areas occupied by all of these coverage, and then stand on their connotations and meanings.

The classification and types of coverage are related to the arts of press editing, as news coverage is done by the technician of the news and the report, while the explanatory coverage is done through the art of journalistic article, investigation and press talk, while the recording coverage is related to the means of highlighting of all kinds, whether they are news and non-news images, shapes and drawings.

This study is based on what was stated in my model:

1) Prioritization (agenda).

2) Media frameworks.

These two models link the social system with the public, and journalism as a means of informing the audience about what information is published.

This study came through the following topics: The first focused on the press coverage in terms of its dimensions, professional values, its types, and its arts, which were distributed between the news, the report, the article, the press talk and the means of highlighting that accompany the coverage in terms of images, drawings and forms, while the second topic focused on the study in it with press coverage and training Public opinion and trends towards feminist activity by focusing on press coverage and the formation of public opinion based on the factors affecting the formation of public opinion, specifically the influence of means of communication and communication in forming public opinion.

As for the third topic of this study, it was devoted to research procedures and tools and measuring the volume and trends of press coverage of feminist activity in the Emirati media in the newspapers subject of the study by conducting a comprehensive survey of the research community. Finally, this study reached a set of conclusions about the press coverage of feminist activity in the Emirati media.

\section{THE PROBLEM OF THE STUDY}

In the twenty-first century, the world has become open to women in all aspects of life, and if she is absent and absent from participating in administrative and leadership work, some societies may not have any percentage indicating their presence and have an impact on participation in decision-making, noting that we find in most developed countries women a presence she interacts in her community, and participates in decision-making at the senior management level.

One of the major obstacles facing the researcher is defining the research problem accurately, as it is much more difficult than finding solutions, because accurate identification means clarity in the researcher's vision or the purpose of the research project that he should perform and the expected results of the research. ${ }^{1}$

The problematic of the study emerges by knowing how the Emirati press deals with issues of leadership and administrative work for Emirati women, and where they are from the real active participation in leadership and administrative posts, social work and others. With the help of the daily Emirati newspapers, the two methods of surveying and content analysis of the study sample

1 Khair Majeed Hamid Al-Attabi: Methods of Social Research, Ministry of Higher Education and Scientific Research, University of Mosul - Dar Al-Kutub for Printing and Publishing, 1991, p.33.

International Journal of Research -GRANTHAALAYAH 


\section{3. (AL-KHALEEJ, AL-BAYAN, AL-ITTIHAD). ${ }^{2}$}

On this basis, the research problem was precisely defined, as this problem lies in ignorance of trends in the press coverage of Emirati feminist activity by the three Emirati newspapers that are the subject of the study, and the size of this coverage therein, by answering the following questions:

What is the volume of press coverage of the Emirati feminist activity, the subject of study in the three newspapers, during the research period?

What are the trends in the press coverage of the newspapers under study (Al-Khaleej, Al-Bayan, Al-Ittihad) of Emirati women's activism?

- What is the size of the difference between the papers under study in terms of press coverage of Emirati feminist activity during the same period covered by the research?

\section{THE IMPORTANCE OF THIS STUDYING}

The United Arab Emirates has made great and serious steps in relying on Emirati women by assuming highranking positions in the country, and in this context, women have achieved achievements represented in the recognition of their active and clear role, through which they embodied their equal rights between women and men. The Arab woman in general is an ambitious and rational woman. Therefore, she did not usually succumb to customs and traditions and self-isolation. She worked, and is still working, to participate in decision-making in various areas of public life. For this comes the addition (importance) of the scientific and practical theory of the study for the following reasons:

\section{THEORETICAL ADDITION}

The interest in the participation of Emirati women came in public life, from the inside and outside in general, through logical and committed interaction with the outside world, as well as transformations, progress and openness in various political, economic and social fields.

UAE women have the right to participate, with all that the federal government offers in various development fields, in various ways, and that stemmed from the understanding of the country's leadership in reading the needs and the necessary steps to be taken in this regard. This in itself is a good sign of respect for the status and being of women.

We should note the following things:

The increase in the desire and need of Emirati women to participate in public work to spread justice between men and women.

- Work to achieve the goal of increasing active participation in the public life of the members of society and participation in decision-making development.

- The importance of the Emirati press in highlighting women as able to participate in decision-making and their ability to leave their mark in the service of the UAE society.

- The importance of shedding light on the laws enacted by the legislative and executive authority (Parliament and Council of Ministers) in giving the opportunity and justice to distribute responsibilities between men and women, in preparation for society to reach an advanced level without discrimination.

\section{SCIENTIFIC IMPORTANCE}

The importance of this study is as follows:

It is a scientific attempt to shed light on the Emirati press's treatment of issues of women's participation in public life and decision-making in the United Arab Emirates.

${ }^{2}$ Omar, S. (2002) Media Research: Its Concept, Procedures' and Methods, Al-Falah Library for Publishing and Distribution' Edition 1, page 214 
- Among the first Emirati studies that attempt to clarify the extent of the space that news of women's activities occupies in the Emirati press

- The importance of the research is based on the importance of the subject itself, Press coverage of women's activities in public life in the Arab world, particularly in recent years, is one of the main factors influencing the development of societies and following the news and highlight it. The media is no longer the preserve of the politicians or the male leaders who until recently were in the forefront of newspaper news, especially in the United Arab Emirates, which is living in a state of permanent renewal and a new resurgence in the formation of the government and the joints of public administrations.

\section{CURRICULUM OF STUDYING}

\subsection{FIRST: THE METHOD}

This study is considered a descriptive and analytical studies, and it aims to study the facts related to a phenomenon, trend, or group of people, or events and situations, with the aim of obtaining confirmed and accurate information, describing the characteristics of the study sample, and working on the estimates and procedures of the study sample about the Emirati press's treatment of issues Women's participation in public work in the United Arab Emirates for the period from 1-6-2020 to 1-10-2020.

The descriptive method is "the most usable method for studying some of the problems and phenomena related to the human being, his positions, opinions and points of view, in his relationship to the media, its means and messages ${ }^{3}$

" Curlinger (2000) defines content analysis: "as a method for studying and analyzing communication on a systematic, objective, and quantitative manner, for the purpose of measuring certain variables." 4 It is a method of analysis, it is a method, and indirectly observing and measuring human behavior, and indirectly investigating.

(Weimar and Dominic) identified the steps of the content analysis approach in ten steps that the researcher should adhere to:

The researcher must formulate the research problem or its hypotheses, determine the sample community that the research problem is affected by, and that the sample is appropriate, choose the units of analysis and define them, then prepare slides for preparing segments (categories) of the content to be analyzed, establish a quantitative calculation system and conduct an exploratory study; With the aim of achieving reliability, coding the content according to definitions, analyzing data and then reaching conclusions, results and research ${ }^{5}$ indicators, the two researchers worked on implementing these steps all together.

\section{THE SAMPLE AND THE RESEARCH COMMUNITY}

The study population was identified in the daily Emirati newspapers, and in order to represent the study community, the two researchers chose three daily newspapers. The published material related to the participation of Jeremiah women in public life for the period from 1-6-2020 until 1-10-2020 was analyzed. It is (Al-Khaleej,AlBayan,Al-Ittihad) When choosing the sample newspapers, the two researchers took into account that they cover all the Emirates of the country.

Sample content analysis study: A representative sample of industrial week topics on the activities of emirates women in public life was published in daily newspapers (Al-Khaleej, Al-Bayan, Al-Ittihad). Content analysis through an analytical resolution newspaper.

${ }^{3}$ Zgheib, Shaima Zulfikar, Research Methods and Statistical Uses in Media Studies, First Edition, The Egyptian Lebanese House (2009), p. 138

${ }^{4}$ Wimmer, and Dominic, Research Methods. (Translation: Salih Khalil Abu Asba). United Arab Emirates University. 1989AD. s. 210

${ }^{5}$ Badr, A. (2008), Media Sciences. Quba Modern House: Cairo. P. 46.

International Journal of Research -GRANTHAALAYAH 


\section{Objectives of the study}

The main objective of this study is to identify how the Emirati press deals with the issues of journalistic coverage of feminist activity in the Emirati media by analyzing the content of journalistic forms and genders, and from this goal branching out a group of sub-goals:

1) Identify the area devoted to shapes and races published in the study newspapers.

2) Identify the topics included in the figures and races published in the study newspapers.

3) Identify the sources of information published, shapes and races in the study

4) newspapers.

5) Identify the trends carried by the figures and races published in the newspapers.

6) Identify the means of highlighting that the study newspapers used in publishing shapes and genders in terms of: (the position in the newspaper and the page, the use of pictures, the use of color in pictures and headlines, the use of frames).

7) Knowing the types of media frameworks used by the study newspapers for the topics of shapes and genders.

8) Identify the fields covered by the topics of shapes and races.

9) Exposing the trends and policies of the Emirati press towards the participation of Emirati women in public work and their participation in decision-making.

\section{Study questions}

1) What is the volume of press coverage of the feminist activity of the Emirati women studied in the three newspapers during the research period?

2) What are the trends in the press coverage of the newspapers under study (Al-Ittihad, Al-Bayan, Al-Khaleej) of the feminist activity of Emirati women?

3) What is the size of the difference between the newspapers (Al-Ittihad, Al-Bayan, and Al-Khaleej) subject of the study in terms of press coverage of the feminist activity of Emirati women during the same period covered by the research?

4) Did the press coverage of the newspapers in question reflect comprehensive and diverse aspects of women's activities, or did they focus on specific areas?

\section{Analysis categories}

The analytical category system is defined as "the system used to classify media content". Its terms have been defined by mohamed abdelhamid in writing (scientific research in media studies) witch are:

\section{Credibility of the curriculum}

First: "Achieving metabolism of classes", which means that the material that has been classified within the framework of another specific category is not accepted.

Second: That the categories system be comprehensive.

Third: The adequacy or suitability of the categories system for the aims of the study, and that the categories are applicable and add something about the media process, and the flexibility of this system and its ability to work with new materials or meanings during the document analysis phase ${ }^{6}$

A content analysis index was prepared based on the (initial) exploratory study on (10\%) of the articles of the three daily newspapers (Al-Ittihad, Al-Bayan, and Al-Khaleej). And in it, the main and sub-categories of analysis were defined as follows:

\section{Categories What was said?}

The categories of what was said in the Emirati press material that was published in the sample newspapers are derived under the names of journalistic forms and journalistic genres, and where these materials will be analyzed according to the rules. 
Journalistic Forms Category: It means "the forms or journalistic arts through which the contents of the participation of women in public work are covered, namely: news (which represent facts) and analyzes (which present an opinion stemming from those facts). ${ }^{7}$

The journalistic forms have been defined as follows:

- The news: It is known as "a real-time report on anything interesting to humanity," and it is "a subtle, unbiased type about a new incident of interest to readers." 8

Procedurally, the news is defined in this study as: The news article related to the participation of women in political work that was published by the Emirati press during the study period from real facts related to Emirati women, or a description of an event or action covered by this press.

- News analysis: It is "everything sheds light on the story." 9

It defines news analysis procedural: it is the various forms of journalism that the Emirati press includes that clarifies and interprets news, such as investigative journalism, article, and column.

- Journalistic investigation: It is "the art of explaining and interpreting and searching for the causes, and the social, economic, political or intellectual factors that lie behind the news, the story, the problem or the apparent idea around which the investigation revolves." 10

A journalistic investigation is defined procedurally as: Examining data and evidence about the cause, and the reason behind which the purpose of publishing, or discussing a topic or issue in a certain field, disappears.

- D-The Essay: It is defined as "a piece of prose that the writer speaks by himself and tells about an experience he practiced, an incident that occurred to him, or his thoughts on a topic." 11

Procedurally it is: a journalist's opinion written on a topic, and it is published in the Emirati press, directed to the public and understood by the majority of people, and the writer gives his own opinion on the topic of the article, with support or opposition.

- E-Column: It is one of the types of opinion material that is published regularly under a fixed title and in a fixed place and bears the signature of its writer and reflects the components of his personality in thinking and expression and achieves the functions of contemporary journalism and media with the aim of developing and advancing society, provided that the area of publishing this article does not exceed an entire column or Part of two columns or one paragraph ${ }^{12}$

It is known as procedurally: it is the column of a journalist who is well known to his readership and is therefore a well-known, experienced, well-educated writer.

Category of the trend: the trend is scientifically defined as "a state of mental readiness that may not be neutral, and it has a dynamic or directive effect on the individual's response to the matters and conditions related to this state." 13

The procedural trend in this study is defined as: the general nature that dominated the contents published by the sample newspapers over the course of the study.

The field category: It is the broad and general field of study (political, developmental, social, initiatives, media, arts, sports, various, others).

Validate the study tool:

The validity test of the tool was performed in two ways

1) The two researchers presented the content analysis form to a group of media referees from the University of Sharjah, Ajman University and the University of Baghdad. With the aim of making sure of their scientific validity, their directions were taken to serve the purposes of the study, and it concluded its final form.

${ }^{7}$ Al-Mousa, A. (2014), Mass Communication, Ithraa Publishing House (University Library): Amman, p. 127-128.

8 -Khadr, S. (1986), Journalism and the Age. Ministry of Culture and Information: Baghdad, P.0. 192

${ }^{9}$ Al-Mousa, A. (2003), Media and Society (Studies in Jordanian, Arab and International Media). Ministry of Culture: Oman, P.O. 199.

10 Ibrahim, I. (2000), The journalistic editorial art between theory and practice. Dar Al-Fajr: Cairo, P.0. 102

${ }^{11}$ Haddad, N. (2002), The Art of Journalism Writing. Dar Al-Kindi: Irbid, p. 218.

12 http://www.abahe.co.uk/\% 85.html 6/25/2020 03:41 pm.

${ }^{13}$ Rashti, c. (1978), The Scientific Foundations of Media Theories. Edition 2, Arab Thought House, p. 626. 
$10 \%$ of the study sample was pretested by reading a number of newspaper editions and extracting the categories analyzed.

\section{DEFINITION OF SAMPLE NEWSPAPERS}

Al Ittihad Newspaper 14 A daily newspaper in the Emirates. Issued by Abu Dhabi Media Company in the Emirate of Abu Dhabi, and it is considered one of the first and oldest newspapers published in the United Arab Emirates. The first issue of Al-Ittihad newspaper was published on October 20,1969, during a period that witnessed the continuous work of the late His Highness Sheikh Zayed bin Sultan Al Nahyan, may God rest his soul, at that time he was making intensive efforts with his brothers, the rulers of the Emirates, to establish the Union of the United Arab Emirates.

The name "Al-Ittihad" bears symbolic and significant meanings, which reflects the fact that "Al-Ittihad" newspaper is the mouthpiece of the UAE, not only as a society, but as a political entity known for its objective positions and orientations. As of April 22, 1972, Al-Ittihad newspaper began publishing daily and continues today.

\section{Albayan Newspaper 15}

A comprehensive political daily published in Dubai, United Arab Emirates. It was established on May 10, 1980.

With it, three daily supplements are issued, "The Mathematical Statement", "The Economic Statement" and "The Five Senses". On Sunday, a cultural supplement entitled "Pathways" will be published with it, and a "Books" supplement and other supplements will be issued on Friday.

In 2012, Al-Bayan managed to achieve the first place "Arab" on the list of the most attended Arab newspapers on social networks, published by Forbes Middle East magazine 16

\section{Al Khaleej Newspaper:17}

It is a daily newspaper issued by the Gulf House for Press, Printing and Publishing in Sharjah, United Arab Emirates, which was established in 1970 by the two brothers Tarim Omran Tarim and Dr. Abdullah Imran Tarim,

with the aim of defending all national issues and advocating for truth everywhere. Since its inception, Dar Al Khaleej has endeavored to pursue the latest technical developments, in addition to providing professional and skilled technical cadres, and the institution currently includes the latest printing machines capable of meeting the needs of the various versions of the house.

It maintains press relations at an international level through agreements with a large number of international newspapers and many news agencies such as the Associated Press, France Press, United Press, Jama Press, and various Arab agencies.

Hundreds of journalists and technicians trained at the highest level, Dar Al Khaleej have a network of foreign offices and correspondents spread around the world. It also has offices in the Arab countries and the Gulf Cooperation Council countries, as well as its offices in the United Arab Emirates.

Dar Al Khaleej opens its arms for constructive and purposeful criticism in all issues and affairs of the hour under the slogan "The truth without fear and the reality without falsehood." They also interact with the interests of the readers, and are always at the center of events.

\section{Theories used}

Two theories will be adopted in this study, namely:

1) Prioritization (agenda).

2) Media frameworks.

14 -https://ar.wikipedia.org/wiki/\%D8\%A7\%D9\%84\%D8\%A7.

${ }^{15}$ https://ar.wikipedia.org/wiki/\%D8\%A7\%D9\%84\%D8\%A8\%D9\%8A\%D8\%A7.

${ }_{16}$ About Al-Bayan, the newspaper website, dated 11/10/2014, a copy reserved July 03, 2017 on the Wayback Machine website.

17 17-https://ar.wikipedia.org/wiki/\%D8\%B5\%D8\%AD\%D9\%8A\%D9\%81\%D8\%A9 
The theory of prioritization (The agenda): This theory is based on the premise that there is a relationship between the way in which the media presents the published material, and the newspaper's interests in the event or topic, and then comes the interest in the form or

the content. Mc Combs identified the factors affecting the agenda setting as follows:

The individual: needs a political orientation, integration, and adaptation to the surrounding circumstances.

Means of communication: influenced by the nature of the political system, the topics at hand, the type of medium, and the level of coverage of the media outlet ${ }^{18} \mathrm{MC}$ combs\& shaw, 1972, says that "there is a correlation between the hierarchical system of meaning given to the same problems by the public and politicians", as the means of communication determine the significance of events and problems, and their hierarchical ranking. Prioritization.

theory urges the recipient on any matter so that he or she should think and feel about what he or she should receive by controlling what he or she publishes, who is the most prominent person in this published material depending on the orientation and the media policy of each media outlet. 19

By analyzing the studies of prioritization, it was found that factors and variables must be taken into consideration towards the priority of the topic, or the type of topic, and they may be tangible, abstract, or curiosity on the part of the public towards the topic, their importance, the most important demographic characteristics of the audience, and when the topic was raised or occurred What are the media outlets that dealt with the issue at the time it occurred, and what was its reflection on the public and society. 20

\section{There are two basic strategies for setting their priorities:}

1) "Study a set of prevailing topics in the media, and among the public, in one or two periods."

2) "Study a single issue in multiple time periods, that is, an extended study. The content analysis method is used to limit the topics that are confirmed by the media." 21

\section{MEDIA FRAMES THEORY}

This theory is considered one of the modern (tributary) theories in communication studies, because the researcher is able to measure the implicit content of the media message that reflects the media policy of the medium, and on the other hand, it provides a systematic explanation of the role of the media in how it shapes ideas and trends of topics, and their impact on the cognitive and emotional response When the audience for topics. ${ }^{22}$

The interest in frameworks theory began in media studies when Schattschneider wrote in 1960 that political conflict is not just a discussion in which the parties to the conflict can agree to define the topics in advance, or to define what the topics of this discussion are, but only authority has the upper hand in developing alternatives to these topics. Raised and determine its topics. " 23

The nativism of the frameworks allows the researcher to measure the implicit content of the media messages reflected by the media, and this theory provides a systematic explanation of the role of the media in shaping ideas and trends towards prominent topics and its relationship to the audience's cognitive and emotional responses to those topics, and this theory assumes that the events do not in themselves have meaning Specifically, it acquires its significance by placing it in a framework that defines it, organizes it and gives it a measure of consistency by focusing on some aspects of the topic and neglecting other aspects. The media framework is that central idea around which events related to a particular issue are organized. ${ }^{24}$

18 8-Ismail, M. (2003), Principles of Communication Science and Theories of Impact. International Publishing and Distribution House, ed. 1. p. 272.

${ }^{19}$ Alaq, b. (2010), Theories of Communication. Al-Yazouri Scientific House for Publishing and Distribution. P. 85

20 Irons, H. And Mr., L. (1998), Communication and its contemporary theories. First edition, The Egyptian Lebanese House:

Cairo. s. 293

${ }^{21}$ Irons, H. And Mr., L. (1998), Communication and its contemporary theories, the same previous source, p. 292.

22 Irons, H. Al-Sayed, the same previous source, p. 384.

${ }^{23}$ Al-Hadidi, M. (2006), Media Theories, Recent Trends in Public and Public Opinion Studies, Nancy Library, Damietta, Egypt, p. 162.

${ }^{24}$ Irons, H. And Mr., L. (1998), Communication and its contemporary theories. Previous source. P. 348. 
Entman defined the framework as identifying certain aspects of reality related to an event or issue and making it more prominent in the media text. Media frameworks contribute to building frameworks for the audience regarding the topic, or the topics that are highlighted in the media content. ${ }^{25}$

This theory works on framing the media message within specific standards and on the interpretation of what affects the opinions and attitudes of the recipient of the message, even if this message does not mean much to the recipient, it may place it within an attractive context in terms of language and wording and focus on a specific text to spread it and draw attention to it in the frame template Social. ${ }^{26}$

Among the most prominent explanatory models that are employed in the qualitative analysis to represent the salient aspects and features contained in the media message is the Robert Entman model. Which defines four functions of media framework analysis. 27

- Define the problem or topic accurately.

- Diagnose the causes of the problem.

- Establish moral judgments.

- Suggest ways of treatment.

The researchers conclude that the news frame is a comprehensive process through which the contact person classifies the story in a specific category and places it in a context that has meaning and significance for the recipient. Frameworks also work to change the belief by shifting the individual's sense of priorities related to the topic, so that the frameworks work through their influence. In the individual's perceptions of what is more important or more appropriate to the issue.

The news frame gives meaning or significance to the news so that it has significance or importance to the audience, as it defines the entrance or angle through which the news can be seen. The news framework is an integral part of the philosophy and ideology of society, as it changes the patterns of societal values with important inputs that affect the communicators when developing and using the news frame, and the news framework is an aid to change media events in a way that helps the recipient understand them.

\section{PREVIOUS STUDIES}

Previous studies help researchers in making the right choice of their research and avoiding repetition of previous problems, and the two researchers can avoid the mistakes made by other researchers 28

For the purpose of avoiding repetition in studying previous problems and searching for new ones, the researchers reviewed previous media studies in the field of press coverage to find out the accumulation of knowledge that specialized in studying the correlation between press coverage and feminist activity or specific engagement relationships without expansion.

The most prominent of these studies that have a direct relationship to the subject of this study can be reviewed as follows:

- Rashid Saeed Al Shamsi research, December 2011 entitled: Empowering Emirati Women, published by the Emirates Center for Strategic Studies and Research.

The research aims to focus on the efforts made by the United Arab Emirates in developing the capabilities of women and rooting their role in the process of building and renaissance in various areas of life, in order to achieve effective community participation in all fields.

The researcher refers to important statistics, including what is related to the participation of Emirati women in ministries and federal bodies, especially their assumption of leadership positions in a number of sectors such as: education, health, labor and social affairs, energy, the water and electricity sector and the UAE Federal National Council.

${ }^{25}$ Wahib, Istabraq (2009) Media treatment of the American occupation of Iraq, content analysis of Newsweek magazine - Arabic version, unpublished MA Thesis, Middle East University, Amman, Jordan. s. 12

${ }^{26}$ Solomon, S. (2000), Theories of learning and their applications in education. Private Golden Pages library, 1 st ed. s. 50.

${ }^{27}$ Salhi, Hatem Ali, Media Trust Blog, July 18-2017 https://hatimalsalehi.blogspot.com/2017/07/framing-theory.html

${ }^{28}$ Khalifa Shehata: Methods of Social Research, Libyan Jamahiriya: University of Qaryounis, 1992, p. 72. 
- Tiffany D. Barens \& Stephanie M. Burchard's study, 2012, entitled "The Descriptive Impact of Representation and Participation of Women in Politics in Sahran (Africa)"

The study aimed at identifying the gap between men and women in political participation in 20 African countries during the years 1999-2008. The descriptive survey method was used. The results of the study revealed that there is political participation of women, and it is increasing.

- Published study, Amanda Bullough \& K, \& Galan KROECK, William Newburry \& Sumit K. Kundu \& Kevin B. Lowe, 2011, titled "The Political Leadership Participation of Women Around the World".

The study aims to identify the power of women's political participation in society. Data were collected from several sources in 181 countries, to perform a linear regression analysis with institutional impacts: business environment, societal development, economic environment, physical and technological infrastructure, political freedom, and culture. The study found that increasing women's political participation in leadership positions needs to re-evaluate business systems and learning opportunities, narrow the gender gap in political empowerment, and study the country's economic situation, political freedom, cultural variables and proximity to power.

- Heather L. Ondercin \& Daniel Jones-White, 2011, entitled "The Gender Scourge: What Impact of Gender Differences in Political Knowledge on Political Participation".

The study aims to explore whether gender differences have an impact on political knowledge, participation, and political activities. ANES data were used for the five elections from 1984 to 2000, how to employ logistical regression, estimate voting probability, influence voting, attendance at meetings, election campaigns, and campaign donations. The study found that the low level of political knowledge of women leads to a lack of basic participation for them, and this gap is most prominent at the higher levels, especially trying to influence voting, attending political meetings and donating to campaigns. Women are more likely than men to be able to wear political dress and work for political campaigns.

- Jeffry A. Karp \& Susan A. Banducci study, 2007. titled “When politics is not just a man's game: Women's representation and political participation".

The study aimed to identify how women are elected to national legislatures, and the impact of participation and positions on the political process in 35 countries. Using data from a comparative study of electoral systems (custom search engines).

The study found that the differences between the sexes in political participation, and political positions are evident in a large number of countries. The participation of women in political work adds positivity through their representation and political positions, but the effects are weak compared to men.

\section{COMMENTARY ON PREVIOUS STUDIES}

- Most of the previous studies that were reviewed neglected the means of highlighting in the press coverage, which plays an important role in imparting realism and credibility in the press coverage of feminist activity in the various fields of life, as well as highlighting the elements of attraction and attention, as this study was distinguished from previous studies in the study of methods The highlight that accompanied this press coverage by listing the pictures in their news, non-news and other forms.

- The two researchers did not find any classification in previous studies of the types of press coverage used in them based on the agreed scientific academic classification (news coverage, explanatory coverage, recording coverage ... etc.)

- -Most of the previous studies focused on the problem of women obtaining their chances of winning or participating in a percentage of the seats in parliament or national councils of the sample countries and neglected cultural, political, scientific and many other activities.

\section{Study concepts}

Press coverage

The process of obtaining data and details of a specific event and information related to it and being aware of its causes, place of occurrence, names of the participants in it, how it occurred and when it occurred, and other 
information that makes the event the owner of the components and elements that make it suitable for publication using various editorial templates and external methods. ${ }^{29}$

It is a work that the journalist does, to obtain information, take the details and developments of the event, the topic, or a statement that answers all the questions that may arise in the mind of the reader about the event that occurred, and works on editing the information, and sends it to publication after obtaining the necessary approval, provided that it is This information supports and explains the basic facts of the events or topic, such as the location of the event, date, time, economic and political conditions, causes, motives and consequences on the basis of which the event occurred. 30

\section{UAE media}

Audio and video satellite channels, newspapers, and printed and electronic magazines in the UAE, which are among the most important, oldest and widespread of the study sample chosen by the researcher. ${ }^{31}$

\section{Feminist Activism}

The different implementation practices of women in governmental and private state institutions, including the performance of roles in the political, administrative, social, cultural and economic sectors, in order to enhance and support the production of policies and approaches that support equality in all legal and societal frameworks. ${ }^{32}$

It is a frame of reference that provides us with information that makes us feel with others or in solidarity with them or get their support, that is, it is a mental and nervous preparation organized around the experience to respond regularly in a likable or unpleasant way, that is, it is an expression of a certain individual's position, either reflects this position in terms of Positive, negative, or neutral, and the trend, whether on the individual or group level, includes a process of evaluation or a specific judgment. ${ }^{33}$

\section{Direction}

The direction of the news is not determined only by the audio news text, as the visual material contributes to determining this direction. The audiovisual text may be objective and not inclined to any direction, whether negative or positive, but the displayed image tends to be negative or positive, and thus determines the direction of the news, and the audience perceives it. According to the sentences of the news text and the accompanying picture, or the comment of the news guest, whether he is an expert, a political analyst, or a military person ... etc. ${ }^{34}$

\section{RESEARCH PROCEDURES AND TOOLS}

For the purpose of determining the volume of press coverage and its trends in newspapers (Al-Khaleej, AlBayan, Al-Ittihad) of feminist activity in the United Arab Emirates, the two researchers conducted a general survey of all journalistic arts that dealt with this topic and for the period under study. The method used in this study is as follows:

\subsection{RESEARCH COMMUNITY}

The research community is represented by three Emirati newspapers subject to study: (Al-Khaleej, Al-Bayan, and Al-Ittihad)

${ }^{29}$ Issa Ayal Majeed, press coverage of the news, Tikrit University, published research, accessed on November 11th. 2020 http://md.carts.tu.edu.iq/images/.

30 Alamuddin, M. (2010) Journalistic investigations as a form of interpretive and investigative journalistic coverage in the controls of security journalistic investigations, 1st Edition, Riyadh: Naif Arab University for Security Sciences. s. 25-26.

${ }^{31}$ Fawzia Al Ali, Muhammad Yunus, Emirati Media, Origin and Development, Al Falah Library, Dubai, 2014, pp. 24-25.

32 Arab Feminist Revival, Possibilities and Necessities, Zina Al-Zaatari, Research Group in the book: Arab Feminism A Critical Vision, A Group of Researchers, Center for Arab Unity Studies - Beirut, 1st Edition, 2012 AD, pg 66.

${ }^{33}$ Farag Abdel Kader: Encyclopedia of Psychology and Psychoanalysis, The Anglo-Egyptian Library, Cairo, Edition 1, 2009, pp. 23-24.

${ }^{34}$ Barakat Abdel Aziz, news material on radio and television, The Egyptian Lebanese House, First Edition, Cairo, 2013, p. 172 International Journal of Research -GRANTHAALAYAH 


\subsection{RESEARCH SAMPLE}

The sample was chosen in a manner that seeks to be precise in order to reach conclusions reflecting the condition of the original society, and given the study's limitation to trends in the press coverage of feminist activity in the Emirati media that represent the community of the analytical study, the two researchers chose a sample of the three newspapers in the rotation method or what is known as the industrial week, Which is the method of regular random sampling, for example (Saturday of the first week, Sunday of the second week, Monday of the third week, Tuesday of the fourth week, Thursday of the fifth week, ... etc.) so that it is an industrial week, to ensure the same time dimension between days Some of them, and giving equal opportunities for all days of spreading the news throughout the week, to represent the sample 35 Thus ensuring that the nature and direction of coverage is truly achieved. The number has reached, and the total number of issues issued by these newspapers which are subject to analysis and interpretation has reached 63, distributed as follows:

- Emirates newspaper Al Khaleej 21 issues.

- The UAE newspaper, Al Ittihad, 21 issues.

- Al Bayan UAE newspaper, 21 issues.

\subsection{FIELDS OF RESEARCH}

The research community can be divided into the following areas:

Spatial domain: It is represented by the actual numbers subject to study in newspapers (Al-Khaleej, Al-Bayan, Al-Ittihad) in the emirate in which the newspaper (electronic version) is published.

The temporal domain: the time period is limited to the issues published by the newspapers in question, from $1 / 6 / 2020$ to $1 / 10 / 2020$.

Thematic area: includes the press coverage, volume and trends in newspapers (Al-Khaleej, Al-Bayan, and AlIttihad) regarding feminist activity in the UAE media, the two researchers enumerated the press editing arts that covered these activities, namely news, report, article and press talk. The outcome of a general survey of these journalistic arts in the newspapers under study was as follows:

- The total number of news and reports that covered news of women's activity in the Emirati media in the newspapers under study reached (200) news and press reports, and the total of articles in the three newspapers reached (8) newspaper articles, and the total number of journalistic talk in the newspapers under study reached (7) press talks That is, the total press coverage of female activity in the Emirati media in the three newspapers reached (215) press articles distributed on the aforementioned arts during the study period.

- The total of the news that covered the news of feminist activity in Al-Ittihad newspaper reached (77) news and reports, and the total of articles in Al-Ittihad newspaper reached (3) newspaper articles and two press interviews, so the total number (82) articles included news coverage of Emirati feminist activity or reference to it in the body The news or the press article in Al-Ittihad newspaper.

- The total of the news that covered women's activity in Al-Bayan newspaper reached (56) news and reports, and the total of press articles in Al-Bayan newspaper reached (3) newspaper articles and three press talks, so the total was (62) topics that included news coverage of Emirati feminist activity or reference to it in The body of the news or the press article in Al-Bayan newspaper.

- The total number of news that covered women's activity in the Emirati media in Al-Khaleej newspaper reached (66) news, reports, and two press articles, while the number of press interviews reached two press interviews, bringing the total to (71) topics that included news coverage of Emirati feminist activity or reference to it in the body The news or the press article in the Gulf newspaper.

\subsection{RESEARCH METHOD}

Most of the methodological research indicates that "researchers can include all members of society in the study if the size of the community is small. Thus, the researcher avoids generalization errors that result from using data

${ }^{35}$ Samir Muhammad Hussein, Media Research, Cairo, Alam Al-Kutub 1990, p. 125.

International Journal of Research -GRANTHAALAYAH 
taken from a part of the society in judging the whole society" 36 Based on that, the researchers adopted the method The comprehensive inventory of the industrial week method for the research community represented by the numbers issued by the newspapers (Al-Ittihad, Al-Bayan, and Al-Khaleej) during the period subject to study and analysis.

\subsection{STATISTICAL METHOD OF RESEARCH}

The researchers used one of the descriptive statistical methods to describe the press coverage in newspapers (Al-Ittihad, Al-Bayan, and Al-Khaleej). This method was represented by frequency and percentage, in addition to using statistical tables with one dimension, and composite scheduling for the purpose of conducting statistical analysis of the results of these tables and their interpretation, in addition to presenting conclusions.

\subsection{SEARCH TOOLS}

To achieve the thesis objectives, the two researchers adopted the following tools:

First / Observation: It means accurate observation of a phenomenon or a group of it with the help of tools and methods that are consistent with the nature of these phenomena in order to know their characteristics, properties and factors involved in them. 37

The two researchers conducted an exploratory study of samples from the newspapers under study and reached to determine the type of trends in these newspapers regarding news of feminist activity in the Emirati media, which they used in building a scale for determining trends in press coverage of these newspapers, and the exploratory study included two phases, the first is to conduct a survey A first is for the research community, and the second is to conduct a comprehensive and exclusive survey of the three newspapers after one month. The two researchers came out with eleven categories for press coverage of news of women's activity in the Emirati media during the study period.

\subsection{TRENDS ANALYSIS FORM}

The two researchers prepared a special form to analyze trends in press coverage of news of feminist activity in the UAE media based on the exclusive and comprehensive survey of the research community, relying on the unity of the idea in building this questionnaire, and this form was presented to a group of arbitrators. ${ }^{38}$

\subsection{IDENTIFY RESEARCH TOPICS AND ANALYZE TRENDS}

Below are the eleven major analysis axes with procedural definitions for each of them:

\section{Social}

It is the category that means the practices, activities, and contributions made by members of society in general, and which works to develop ties, relationships and the level of services that lead to securing the individual's needs and desires, and working to improve and increase his ability to understand his problems, and his engagement with members of the society in which he lives, to reach To a better life, with a focus on the human side, which enhances the interdependence and integration of the components of society.

\section{Medicine and health sciences}

${ }^{36}$ Khair Majeed Hamid Al-Atabi: Previous Source, p. 75.

${ }^{37}$ Samir Muhammad Hussein: Studies in Scientific Research Curricula, Media Research, Cairo: The World of Books, 1999, p. 147.

38 *The questionnaire was arbitrated by professors who are Professors Prof. Dr.. Hussein Harf, Prof. Dr. Mohamed Sabry, Dr. Taiba Jamil, Dr. Mohammed Jassim Al-Obaidi 
This category means everything related to news and activities that deal with human health, news of decisions and data related to public health, as well as health-related issues such as water, safe food, climate change, and disease control.

\section{Education}

This category means all news of activities related to comprehensive educational care, as well as news related to decisions, guidelines, methods, methods and efforts that enable students and individuals to acquire knowledge and skills that facilitate their full possession of their various abilities and use them in the best way.

\section{Initiatives}

This category means all business news, actions and voluntary contributions that are issued by the volunteer initiators to work in a manner that is characterized by awareness and awareness and the ability to leave positive and sustainable effects through exerting maximum efforts without asking the initiator to do so.

\section{Events and conferences}

This category means news of activities related to participation in management and supervision of conferences or organizing exhibitions, or those related to participation in event management and the making of events and parties.

\section{Politics and International Relations}

This category means news of activities related to participation in events or activities or a phenomenon of mutual interactions between the political and economic interactions between the United Arab Emirates and its regional and international environment and in various fields.

\section{Biography and Achievements}

This category means files and press reports that include a summary that sheds light on the history and the important achievements that Emirati women have achieved in various fields.

\section{Flags}

This category means all news of activities related to the participation or contributions of Emirati women in various media fields.

\section{Arts}

This category means all news of activities related to the participation or contributions of Emirati women in the various artistic fields, theater, cinema, plastic arts, television.

\section{Sport}

This category means all news of activities or achievements related to the participation or contributions of Emirati women in various sports fields locally and internationally.

\section{Economy}

This category means all news of economic activity, "which is the effort made by individuals in order to satisfy desires and satisfy basic human needs, or in order to gain money, and to provide various productive goods and services." 39

\subsection{VALIDITY AND RELIABILITY OF THE ANALYSIS}


In estimating the level of reliability of the research results and its degree, the two researchers depended on Danielson's assessment 40 of the reliability coefficient by calculating the percentage of agreement as a result of the ratio of the number of axes of press coverage in its various arts agreed upon by the coders to the total number of these axes in all their arts that the coders worked on multiplied by 100 and followed The two researchers, the testretest method, where one of the researchers ${ }^{41}$ conducted the test again on the same material that was subjected to measurement and coding by the first researcher using the same coding instructions on 215 press articles covering news of feminist activities distributed in the arts of press editing (Arts News, report, article, press talk). In (Al-Bayan, Al-Ittihad, and Al-Khaleej newspapers), after matching the results of the original researchers' test with the results of the third researcher's test, it was found that the reliability coefficient $=86.52 \%$, by dividing the number of press materials agreed upon in the coding of 270 by the total number of articles of 215 multiplied by 100 .

The two researchers investigated the level of honesty in the results of the research by using the special equation 42 by extracting the self-validity coefficient through the relationship between the reliability coefficient and selfvalidity.

The two researchers used a scale to compare coverage in the journalistic arts between the three newspapers based on the percentage system, by dividing the total frequency of coverage for each newspaper by the total number of coverage in the three newspapers and multiplying the result by one hundred.

\section{FIELD STUDY AND RESULTS}

Results of quantitative analysis of press coverage

Table 1: Press coverage of the activities of Emirati women in Al-Ittihad newspaper

\begin{tabular}{|c|c|c|c|}
\hline \multirow{2}{*}{$\mathrm{N}$} & Categories & \multicolumn{2}{|c|}{$\begin{array}{c}\text { Press coverage of women's activities, quantities and percentages in Al- } \\
\text { Ittihad newspaper }\end{array}$} \\
\cline { 3 - 4 } & & $\mathrm{C}$ & $\mathrm{P} \%$ \\
\hline 1 & social & 11 & $13.41 \%$ \\
\hline 2 & Medicine and health sciences & 8 & $9.75 \%$ \\
\hline 3 & Education & 9 & $10.97 \%$ \\
\hline 4 & Initiatives & 9 & $10.97 \%$ \\
\hline 5 & Events and conferences & 9 & $8.37 \%$ \\
\hline 6 & Politics and international & 7 & $9.75 \%$ \\
\hline 7 & relations & 8 & $7.31 \%$ \\
\hline 8 & Biography and achievements & 6 & $6.09 \%$ \\
\hline 9 & Flags & 5 & $8.35 \%$ \\
\hline 10 & Arts & 7 & $3.65 \%$ \\
\hline 11 & sport & 3 & $100 \%$ \\
\hline 12 & Economy & 82 & \\
\hline
\end{tabular}

Comment on the table:

Table (1) category (social) represents the press coverage of Al-Ittihad newspaper of Emirati women's activities, as this category ranked first with a rate of $13.41 \%$. The categories (initiatives, education, events and conferences) ranked second with a rate of $10.97 \%$ for each, and the categories (medicine and health sciences, biography and achievements) came in third place, with a ratio of nearly $10 \%$ for each, and the category (politics and international

${ }^{40}$ Danielson's evaluation of the reliability coefficient refers to the coding of the articles agreed upon between the two divided by the total *number of press materials that the coders worked on. For more, see: Dr. Muhammad Abdel Hamid, Content Analysis in Media Research, Al-Hilal House and Library: Beirut, 2008-2009, p. 217.

41 The self-validity coefficient = the square root of the reliability coefficient. For more, see: Saad Abdel-Rahman, Theoretical and practical psychological analogy, Volume 3, Dar Al-Fikr Al-Arabi: Cairo, 1998, p. 186

42 The researcher, Assistant Professor Khalil Al-Qaisi, re-tested and applied the same coding mechanisms and instructions to the press materials that covered news of feminist activities in their various editorial arts and which were subjected by the original researchers to measurement and coding. 
relations) ranked The fourth with a percentage of $8.35 \%$, while the same center participated in the (Sports) category with the same rate of $8.35 \%$, and the (Arts) category came in the fifth place with a rate of more than $6.0 \%$, while the economic activities category came in the dominant and last place with $3.65 \%$.

Table 2: Press coverage of the activities of Emirati women for Al-Bayan newspaper

\begin{tabular}{|c|c|c|c|}
\hline $\mathrm{N}$ & Categories & \multicolumn{2}{|c|}{$\begin{array}{c}\text { Press coverage of women's activities, quantities and percentages in Al- } \\
\text { Bayan newspaper }\end{array}$} \\
\cline { 3 - 4 } & & $\mathrm{C}$ & $14.51 \%$ \\
\hline 1 & Social & 9 & $8.06 \%$ \\
\hline 2 & Medicine and health sciences & 5 & $9.67 \%$ \\
\hline 3 & Education & 6 & $14.51 \%$ \\
\hline 4 & Initiatives & 9 & $14.51 \%$ \\
\hline 5 & Events and conferences & 9 & $11.92 \%$ \\
\hline 6 & Politics and international & 7 & $4.83 \%$ \\
\hline 7 & relations & 3 & $6.45 \%$ \\
\hline 8 & Biography and achievements & 4 & $6.45 \%$ \\
\hline 9 & Flags & 4 & $4.83 \%$ \\
\hline 10 & Arts & 3 & $4.83 \%$ \\
\hline 11 & Sport & 3 & $100 \%$ \\
\hline 12 & Economy & 62 & \\
\hline
\end{tabular}

Comment on the table:

Table (2) represents the press coverage of Emirati women's activities, in the category (Initiatives, Events and Conferences) in Al-Bayan Newspaper, as these two categories ranked first in coverage with a rate of $14.51 \%$ for each, while the same center shared with them a category (social) and the same percentage in coverage Journalist for Al Bayan newspaper.

As for the (politics and international relations) category, it ranked second, with a percentage of nearly $12 \%$. And the category (Education and Teaching) ranked fourth with a rate of 9.67. The third place was for the category (Medicine and Health Sciences), which came at a rate of more than $8.0 \%$.

And in fourth place came two categories (media, arts), which shared dusty areas, at a rate of $6.45 \%$ each. As for sports, despite the great masses the group enjoys, it ranked fifth with less than $5.0 \%$. As for the economic activities category, it shared the same rank and proportion with sports.

Table 3: Press coverage of the activities of Emirati women for Al Khaleej newspaper

\begin{tabular}{|c|c|c|c|}
\hline \multirow{2}{*}{$\mathrm{N}$} & Categories & \multicolumn{2}{|c|}{$\begin{array}{c}\text { Press coverage of women's activities and their quantities and percentages in } \\
\text { Al-Khaleej newspaper }\end{array}$} \\
\cline { 3 - 4 } & & $\mathrm{C}$ & $\mathrm{P} \%$ \\
\hline 1 & Social & 14 & $19.71 \%$ \\
\hline 2 & Medicine and health sciences & 6 & $8.45 \%$ \\
\hline 3 & Education & 10 & $9.08 \%$ \\
\hline 4 & Initiatives & 7 & $8.45 \%$ \\
\hline 5 & Events and conferences & 6 & $8.45 \%$ \\
\hline 6 & Politics and international & 6 & $7.04 \%$ \\
\hline 7 & relations & 5 & $7.04 \%$ \\
\hline 8 & Biography and achievements & 5 & $5.63 \%$ \\
\hline 9 & Flags & 4 & $7.04 \%$ \\
\hline 10 & Arts & 5 & $4.22 \%$ \\
\hline 11 & Sport & 3 & $100 \%$ \\
\hline 12 & Economy & 71 & \\
\hline
\end{tabular}

Comment on the table: 
Table (3) represents the press coverage in Al Khaleej newspaper of the activities of Emirati women, for the category (social), as it ranked first with a rate of about $19.71 \%$, while the category (education) ranked second with a rate of $14.08 \%$, while the category (initiatives) ranked third. By about $10 \%$, while in fourth place came the category (events and conferences), with a rate of $8.45 \%$. As for the category (politics and international relations), it shared the fourth place with the category (events and conferences), with the same percentage. As well as the category (Medicine and Health Sciences), with the same rate of $8.45 \%$. The categories (media, sports, biography and achievements) shared the fifth place with $7.04 \%$ for each of them, while the (arts) category came sixth with $5.63 \%$, while the economic activity category came last with $4.22 \%$.

\section{COMPARISON OF THE VOLUME OF PRESS COVERAGE IN THE THREE NEWSPAPERS}

Table 4: Comparison of the press coverage of feminist activity between Al-Ittihad, Al-Bayan and Al-Khaleej newspapers according to the analysis categories:

\begin{tabular}{|c|c|c|c|c|c|c|c|c|}
\hline $\begin{array}{l}\text { The sum of the total percentage in } \\
\text { coverage for each category in the }\end{array}$ & \multicolumn{2}{|c|}{$\begin{array}{l}\text { Al-Khaleej } \\
\text { newspaper }\end{array}$} & \multicolumn{2}{|c|}{$\begin{array}{l}\text { Albayan } \\
\text { newspaper }\end{array}$} & \multicolumn{2}{|c|}{$\begin{array}{l}\text { Alkhaleeg } \\
\text { newspaper }\end{array}$} & \multirow[t]{2}{*}{ Categories } & \multirow[t]{2}{*}{$\bar{N}$} \\
\hline$\%$ & $\%$ & $\mathrm{C}$ & $\%$ & $\mathrm{C}$ & $\%$ & $\mathrm{C}$ & & \\
\hline$\% 47.63$ & $\% 19.71$ & 14 & $\% 14.51$ & 9 & $\% 13.41$ & 11 & social & 1 \\
\hline$\% 26.26$ & $\% 8.45$ & 6 & $\% 8.06$ & 5 & $\% 9.75$ & 8 & $\begin{array}{c}\text { Medicine and } \\
\text { health sciences }\end{array}$ & 2 \\
\hline$\% 34.72$ & $\% 14.08$ & 10 & $\% 9.67$ & 6 & $\% 10.97$ & 9 & Education & 3 \\
\hline \%35.33 & $\% 9.85$ & 7 & $\% 14.51$ & 9 & $\% 10.97$ & 9 & Initiatives & 4 \\
\hline \%33.93 & $\% 8.45$ & 6 & $\% 14.51$ & 9 & $\% 10.97$ & 9 & $\begin{array}{c}\text { Events and } \\
\text { conferences }\end{array}$ & 5 \\
\hline$\% 28.72$ & $\% 8.45$ & 6 & $\% 11.92$ & 7 & $\% 8.35$ & 7 & $\begin{array}{c}\text { Politics and } \\
\text { international } \\
\text { relations }\end{array}$ & 6 \\
\hline$\% 21.62$ & $\% 7.04$ & 5 & $\% 4.83$ & 3 & $\% 9.75$ & 8 & $\begin{array}{c}\text { Biography and } \\
\text { achievements }\end{array}$ & 7 \\
\hline$\% 21.00$ & $\% 7.04$ & 5 & $\% 6.45$ & 4 & $\% 7.31$ & 6 & Flags & 8 \\
\hline$\% 18.17$ & $\% 5.63$ & 4 & $\% 6.45$ & 4 & $\% 6.09$ & 5 & Arts & 9 \\
\hline$\% 20.00$ & $\% 7.04$ & 5 & $\% 4.83$ & 3 & $\% 8.35$ & 7 & Sport & 10 \\
\hline$\% 12.7$ & $\% 4.22$ & 3 & $\% 4.83$ & 3 & $\% 3.65$ & 3 & Economy & 11 \\
\hline & $\% 100$ & 71 & $\% 100$ & 62 & $\% 100$ & 82 & Total & 12 \\
\hline
\end{tabular}

It is evident from the foregoing in Table (4) that the total volume of press coverage of feminist activities in the three newspapers under study in journalistic arts amounted to 215 repetitions distributed among the three newspapers.

The comparison process between the three newspapers under study resulted in a number of indicators and results that show the extent of the acquisition of each of the analysis categories on the general percentages of the three newspapers' coverage of Emirati women's news in the regular random sample that the researchers counted, as follows:

First: The (social) category occupied the first place in the volume of press coverage among the axes in the three newspapers at a rate of $47.63 \%$, and the order of the newspapers in it was according to the percentages reached by the two researchers, respectively: 
Second: The (Initiatives) category ranked second in the volume of press coverage among the ranking of categories in the three newspapers, at a rate of $35.33 \%$, and the order of the newspapers therein was according to the percentages reached by the two researchers respectively:

1) Al-Bayan Newspaper: its coverage for this category was $14.51 \%$.

2) Al Ittihad Newspaper: Its coverage rate for this category reached $10.97 \%$.

3) Al Khaleej Newspaper: its coverage rate for this category was $9.85 \%$.

Third: The (Education and Teaching) category ranked third in the volume of press coverage among the rankings of the $\mathrm{R}$ categories in the three newspapers, with a rate of $34.72 \%$.

1) Al Khaleej Newspaper: The coverage rate for this category was $14.08 \%$.

2) Al-Ittihad newspaper: as its coverage rate in this category reached $10.97 \%$.

3) Al-Bayan Newspaper: The coverage rate for this category is $9.67 \%$.

Fourth: The (Events and Conferences) category ranked fourth in the volume of press coverage among the ranking of categories in the three newspapers, with a rate of $33.93 \%$.

1) Al-Bayan Newspaper: Its coverage rate for this category was $14.51 \%$.

2) Al Ittihad Newspaper: Its coverage rate for this category reached $10.97 \%$.

3) Al Khaleej Newspaper: its coverage rate for this category was $8.45 \%$.

Fifth: The category (politics and international relations) ranked fifth in the volume of press coverage among the ranking of the categories in the three newspapers, at a rate of $28.72 \%$, and the order of the newspapers in it was according to the ratios reached by the researchers, respectively:

1) Al-Bayan Newspaper: its coverage for this category in the news reached $11.92 \%$.

2) Al Khaleej Newspaper: Its coverage for this category in the news reached $8.45 \%$.

3) Al Ittihad Newspaper: Its coverage for this category in the news reached $8.35 \%$.

Sixth: The topic (Medicine and Health Sciences) ranked sixth in the volume of press coverage among the ranking of categories in the three newspapers, at a rate of $26.26 \%$, and the order of newspapers in it was according to the ratios reached by the researchers, respectively:

1) Al-Ittihad newspaper: its coverage rate for this category was $9.75 \%$.

2) Al Khaleej Newspaper: Its coverage rate for this category reached $8.45 \%$.

3) Al-Bayan Newspaper: Its coverage rate for this category reached 8.06\%.

Seventh: The "Biography and Achievements" category ranked seventh in the volume of press coverage among the ranking of categories in the three newspapers with a rate of $21.62 \%$. The ranking of newspapers in it was according to the percentages reached by the researchers, respectively:

1) Al-Ittihad newspaper: its coverage rate for this category was $9.75 \%$.

2) Al Khaleej Newspaper: its coverage for this category reached 7.04\%.

3) Al-Bayan Newspaper: its coverage rate for this category was $4.83 \%$.

Eighth: The (media) category in covering news of feminist activities ranked eighth in the volume of press coverage in journalistic arts among the ranking of the axes in the three newspapers, at a rate of $21.00 \%$, and the order of newspapers in it was according to the percentages reached by the researchers in the (media) axis as follows:

1) Al-Ittihad newspaper: its coverage rate for this category was $7.31 \%$.

2) Al-Bayan Newspaper: its coverage rate for this category was $6.45 \%$.

3) Al Khaleej Newspaper: its coverage rate for this category was $7.08 \%$.

Ninth: The category (Sports) ranked ninth in the volume of press coverage among the three main topics in the three newspapers, at a rate of $20.00 \%$.

1) Al Ittihad Newspaper: its coverage rate for this category was $8.35 \%$.

2) Al-Bayan Newspaper: its coverage rate for this category was $4.83 \%$.

3) Al Khaleej Newspaper: its coverage rate for this category was 7.04\%.

Tenth: As for the (arts) category, it ranked tenth with a percentage of $18.17 \%$, and it came in the three newspapers 'ranking as follows:

1) Al-Bayan Newspaper: its coverage for this category was $6.45 \%$.

2) Al-Ittihad Newspaper: its coverage rate for this category reached $6.09 \%$.

3) Al Khaleej Newspaper: its coverage rate for this category was $5.63 \%$.

Eleven: The (Economic) category ranked eleventh in the volume of press coverage among the ranking of the categories in the three newspapers, at a rate of $12.7 \%$.

1) Al-Ittihad Newspaper: its coverage rate for this category was $3.65 \%$.

International Journal of Research -GRANTHAALAYAH 
Trends in Press Coverage of Feminist Activity in the UAE Media: An Analytical Study

2) Al-Bayan Newspaper: its coverage rate for this category was $4.83 \%$.

3) $\mathrm{Al}$ Khaleej Newspaper: its coverage rate for this category was $4.22 \%$.

\section{INFERENCES AND CONCLUSION}

In light of the aforementioned comparison of the volume of press coverage of feminist activity in the United Arab Emirates, and if we want to know the groups that won the largest percentage in the three newspapers combined, the results and indicators that were nominated for the quantitative analysis are as follows:

1) The press coverage of the news of Emirati women's activities in the three newspapers gave the highest percentage of activities of a social nature, as it came in first place by collecting the percentages of the three newspapers combined in this category, with a total ratio of $47.63 \%$, which placed it in the first place. The news of the "General Emirati Women's Union" and the empowerment of Emirati women is issued according to a strategy that includes development programs and projects that advance the status and capabilities of women in the UAE and bring about fundamental changes in many issues of concern to Emirati women, childhood, motherhood, family and development, by combining and harmonizing with the activities and activities of the Supreme Council for the Family and Childhood. This indicates that the nature of activities with social dimensions was dominant in the press coverage of Emirati women's activities in the newspapers under study.

2) While the press coverage of the news of Emirati women's activities in the three newspapers gave the second highest percentage of activities related to voluntary initiatives and actions of a humanitarian nature related to sustainability work, as it came in second place by collecting the percentages of the three newspapers combined in this axis, with a total percentage of $35.33 \%$, which placed this category of the activities in the second place, which indicates that the nature of the activities with voluntary dimensions was the predominant second degree in the press coverage of Emirati women's activities in the newspapers under study.

3) Press coverage of the news of Emirati women's activities in the three newspapers gave the third highest percentage of activities related to the education sector, as this category came in third place by collecting the percentages of the three newspapers combined in this axis, with an overall ratio that came close to the category of voluntary initiatives and actions, reaching $34.72 \%$, Which places this category of activities in third place, which indicates that the nature of activities related to universities, education and teaching was the dominant third degree in the press coverage of Emirati women's activities in the newspapers under study.

4) One of the interesting indicators is that the press coverage was granted to news of Emirati women's activities related to events and conferences in the three newspapers. The fourth highest percentage of Emirati women's participation in activities related to this very vital sector in the United Arab Emirates, despite the circumstances that were accompanied by the instructions and directives of the health authorities in the country related to The safety of society in limiting the spread of the Corona pandemic and reducing the risks, as this category came in fourth place by collecting the percentages of the three newspapers combined in this axis and with a total percentage close to the category of activities related to education, as it reached in its total form 33.93\%, which put this The category of activities is in the fourth place, which indicates that the nature of activities related to the participation of Emirati women in organizing events and conferences was prominent and remarkable in the third degree in the press coverage of Emirati women's activities in the newspapers under study.

5) While the press coverage of the news of Emirati women's activities in the three newspapers gave the fifth the highest percentage of activities that Emirati women began to address in areas related to political decisionmaking, the relationship of the United Arab Emirates with its regional and international surroundings, and the activities associated with it from a distinguished presence in the Ministerial Council, the Federal National Council or Some events that are represented in meetings, meetings or discussions at various levels.

The researchers attribute this to the decisions related to increasing the representation of Emirati women in various institutions, especially the Federal National Council, in which the percentage of women's representation in it has reached 50\%, and increasing the representation of women in the Council of Ministers and its affiliated bodies and other departments. In addition to the leadership and management of women for a number of various activities 
and activities, it is necessary to refer to historical precedents in the areas of empowering women in the country, at the regional level for Emirati women, the most prominent of which was the election of the first woman as President of the Federal National Council, in addition to the presence of nine women ministers in the government, Among them is the youngest female minister in the world who received the youth portfolio, leading to the decision of the equal representation of her brother in the Federal National Council, and this is a clear and clear indicator that expresses the community's belief in the capabilities and capabilities of women, and their participation in political decision-making, as the owner of national, social and humanitarian knowledge, skills and experiences that is significant Out.

Therefore, this category came in fifth place by collecting the percentages of the three newspapers combined in this category, with a total rate of $28.72 \%$, which placed this category in a prominent position in the press coverage of Emirati women's activities in the newspapers under study.

\section{SOURCES OF FUNDING}

This research received no specific grant from any funding agency in the public, commercial, or not-for-profit sectors.

\section{CONFLICT OF INTEREST}

The author have declared that no competing interests exist.

\section{ACKNOWLEDGMENT}

None.

\section{REFERENCES}

[1] Al-Mousa, A. (2003), Media and Society (Studies in Jordanian, Arab and International Media). Ministry of Culture: Oman.

[2] Abdul Hamid, M. (2004), Scholarly Research in Media Studies. The World of Books: Cairo.

[3] Alam al ddin, M. (2010) Journalistic investigations as a form of interpretive and investigative journalistic coverage in the controls of security journalistic investigations, 1st Edition, Riyadh: Naif Arab University for Security Sciences.

[4] Al-Bayan newspaper website, accessed 11/10/2014, copy reserved July 03, 2017 on Wayback Machine.

[5] Alaq, b. (2010), Theories of Communication. Al-Yazouri Scientific House for Publishing and Distribution.

[6] Al-Mousa, A. (2014), Mass Communication, Ithraa Publishing House (University Library): Amman.

[7] Al-Hadidi, M. (2006), Media Theories, Recent Trends in Public Studies and Public Opinion, Nancy Library, Damietta, Egypt.

[8] Badr, A. (2008), Media Sciences. Quba Modern House: Cairo.

[9] Barakat Abdel Aziz, news material on radio and television, The Egyptian Lebanese House, 1st Edition, Cairo, 2013.

[10] Fawzia Al Ali, Muhammad Yunus, Emirati Media, Origin and Development, Al Falah Library, Dubai, 2014.

[11] Farag Abdel Kader: Encyclopedia of Psychology and Psychoanalysis, The Anglo-Egyptian Library, Cairo, Edition 1, 2009.

[12] Haddad, N. (2002), The Art of Journalism Writing. Dar Al-Kindi: Irbid.

[13] Ibrahim, I. (2000), The journalistic editorial art between theory and practice. Dar Al-Fajr: Cairo.

[14] Ismail, M. (2003), Principles of Communication Science and Theories of Impact. International Publishing and Distribution House, Edition. 1.

[15] Issa Ayal Majeed, press coverage of the news, Tikrit University, published research, accessed on November 11th. 2020 http://md.carts.tu.edu.iq/images/.

[16] Khadr, S. (1986), Journalism and the Age. Ministry of Culture and Information: Baghdad. 
[17] Khair Majeed Hamid Al-Attabi: Methods of Social Research, Ministry of Higher Education and Scientific Research, University of Mosul - Dar Al-Kutub for Printing and Publishing, 1991.

[18] Khalifa Shehata: Methods of Social Research, Libyan Jamahiriya: University of Garyounis, 1992.

[19] makkawi, H. And Mr., L. (1998), Communication and its contemporary theories. First edition, The Egyptian Lebanese House: Cairo.

[20] Omar, S. (2002) Media Research: Its Concept, Procedures, and Methods, Al-Falah Library for Publishing and Distribution, Edition 1.

[21] Rashti, j. (1978), The Scientific Foundations of Media Theories. Edition 2, Arab Thought House.

[22] Sulaiman, S. (2000), Theories of learning and their applications in education. Private Golden Pages library,

[23] 1st ed.

[24] Salhi, Hatem Ali, Media Trust Blog, July 18-2017 https://hatimalsalehi.blogspot.com/2017/07/framingtheory.html

[25] Samir Muhammad Hussein, Media Research, Cairo, Alam Al-Kutub 1990.

[26] Samir Muhammad Hussein: Studies in Scientific Research Curricula, Media Research, Cairo: The World of Books, 1999.

[27] Saad Abdel-Rahman, Theoretical and practical psychological analogy, 3rd Edition, Dar Al-Fikr Al-Arabi: Cairo, 1998.

[28] Wahib, Istabraq (2009) Media treatment of the American occupation of Iraq, content analysis of Newsweek magazine - Arabic version, unpublished MA Thesis, Middle East University, Amman, Jordan.

[29] Zina Al-Zaatari, Arab Feminist Revival, Possibilities and Necessities, Research Group in the book: Arab Feminism a Critical Vision, Researchers Group, Center for Arab Unity Studies - Beirut, 1st Edition, 2012.

[30] Zugheib, Shaima thu alfikar, Research Methods and Statistical Uses in Media Studies, First Edition, The Egyptian Lebanese House (2009).

[31] http://www.abahe.co.uk/\% 85.html 6/25/2020 03:41 pm.

[32] https://ar.wikipedia.org/wiki/\%D8\%A7\%D9\%84\%D8\%A7

[33] https://ar.wikipedia.org/wiki/\%D8\%A7\%D9\%84\%D8\%A8\%D9\%8A\%D8\%A7

[34] https://ar.wikipedia.org/wiki/\%D8\%B5\%D8\%AD\%D9\%8A\%D9\%81\%D8\%A9

[35] https://mawdoo3.com/\%D8\%A8\%D8\%AD\%D8\%AB\%D8\%A7 Accessed November 12, 2020. 